\title{
Asymmetric effect of financial development and remittance on economic growth in MINT economies: an application of panel NARDL
}

\author{
Jamiu Adetola Odugbesan * (1), Tomiwa Adebayo Sunday and Gbolahan Olowu
}

\begin{abstract}
The empirical analysis examines the asymmetric effect of financial development and remittance on economic growth in MINT nations (Mexico, Indonesia, Nigeria, and Turkey). The present study utilized panel data covering the period from 1980 to 2019. The research objectives are to address the questions: (a) Is there a long-run association between economic growth and the regressors? (b) Do financial development and remittance trigger MINT nations' economic growth? Moreover, the present study applied both linear panel ARDL and the novel panel nonlinear ARDL to capture the asymmetric impact of development and remittance on economic growth. The outcomes of the linear ARDL disclosed that both financial development and remittance triggers economic growth positively. Furthermore, the outcomes of the NARDL disclosed that both positive and negative shocks in financial development increase economic growth. In addition, a positive and negative shock in remittance increases economic growth in the long-run.
\end{abstract}

Keywords: Financial development, Remittance, Economic growth, Nonlinear panel ARDL, MINT

JEL Classification: C01, O11, O23, O40

\section{Introduction}

The issues of financial development and remittances in respect of their relationship to the economic growth have been receiving tremendous attentions in the literature. For instance, both financial development and remittances have been identified among the significant drivers of economic growth, most especially the developing countries $[17,32]$. The contributions are found in the ability to lower credit assessment cost, financial market that is efficient and functional which can assist in channeling the remittances to investment that would yield higher returns and in turn leads to economic growth [22]. It is also argued in the literature that the remittances could be a substitute for inefficient credit markets that could assist the local investors in financing their businesses instead

*Correspondence: odugbesanadetola@gmail.com

Department of Business Administration, Faculty of Economics

and Administrative Science, Cyprus International University, Mersin 10, North Cyprus, Turkey of going for the commercial bank loans which could be inaccessible due to lack of collateral [37].

Meanwhile, some authors opined that the inflow of remittance to the recipients' countries, most especially the developing countries, is a means of compensating those countries for the brain-drain that is peculiar to them through emigration, and the authors believe the remittance will contribute to the economic growth of the destination countries [28, 32, 39, 48]. The record of World Bank shows that prior to 2017, the remittance flows to the developing countries experienced a downturn in 2015 and 2016. A decrease of $1 \%$ and 2.4 percent were recorded for 2015 and 2016, respectively [55]. Though, at the same time, Europe and Central Asia countries also experienced the decline, but Latin America and Caribbean recorded an increase of about $6.9 \%$ remittance flows to their region. Even though a downturn was experienced in the remittance flows to the developing countries, $3.3 \%$ increase was experienced in the year 2017, and $10.8 \%$ increase was projected for 2018 [57]. 
The MINT is the acronyms for the new emerging economic block coined after BRICS in the year 2012 [30]. The block consists of Mexico, Indonesia, Nigeria, and Turkey. Durotoye [20], Odugbesan and Rjoub [39] posited that these countries are believed to be a potential economic force within their respective region and also played significant functions on the international economic relations. In addition, the four countries according to World Bank [56] are increasing in their GDP and likely to continue unabated for some years to come. Moreover, the MINT countries have some resemblance in terms of their characteristics in the area of their youthful population and the location advantages [6]. The larger percentage of the four countries falls in the youth categories, also they are they have location advantages as a result of their location proximity to developed countries, for instance, Mexico is a neighbor to the America, Indonesia is close to China, Nigeria is the economic hub of Africa, while Turkey is located close to the European Union. In 2012 when MINT block was coined by Goldman Sachs, Kokotovic and Kurecic [30] observed that Mexico, Indonesia, Nigeria, and Turkey were ranked 14th, 16th, 39th, and 17th positions, respectively, in the world economies ranking. However, by 2018, World Bank [56] shows that their positions have changed to 15 th, 16 th, 31 st, and $18^{\text {th }}$, respectively, while its projected that by 2023 , Nigeria and Turkey would have changed to 20th and 17th positions in the world economies ranking. In addition, two of the MINT countries (Mexico and Nigeria) were among the ten highest remittances countries in the world [56].

The debates on the sources of economic growth in the literature have been on for decades, and till now, the search for the drivers of economic growth is still dominating the literature which implies that it is exhaustive. Included but not limited factors such as physical capital investment, surplus labor, technological changes, foreign direct investment, trade openness, resources availability, and foreign aids dominated the classical literatures, and the contemporary scholars includes factors such as research and development, financial development, financial inclusion, remittances and so on. However, the scholars' attentions have been shifted to the contributions of financial development and remittance to the economic growth, having observed that the remittance could bridge the gap of inequality by investing the fund in creating jobs by the beneficiaries, which can ameliorate the poverty [8]. Giuliano and Ruiz-Arranz [22] opined that through an investment channel, remittance has the capability of promoting the economy where the credit need of the people are not met by the financial sector and concluded that in a country with less developed financial systems, remittances can assist in overcoming the liquidity constraints, and it should be encouraged.
In view of the relative new development of the MINT block as an emerging world economic block, the studies that are specifically focused on the MINT countries are still few and scant in comparison to BRICS. Among the few studies that focus on the MINT countries is the work of Durotoye [20] who did a descriptive study on the opportunities and challenges of the economic block. Another study by Öztürk and Yildirim [41] tried to evaluate the environmental Kuznet curve, but found ambiguous results, but suggested that the MINT countries have some potential advantages that could advance them to be among the ten world's largest economies in the coming decades. Kokotovi and Kurecic [30] examined some selected economic features on the economic growth of the MINTs and found that though the block could have significant functions to perform in international relations, but does not possess a significant economic threat to the BRICS countries. More recently, Asongu et al. [6] did a comparative study between MINT and BRICS, the study examines the determinants of FDI in fast-growing economies, while Odugbesan and Rjoub [39] study focuses on the influence of remittance on the economic growth of MINT countries, the study found mixed results among the countries.

From the above discussion, it becomes apparent that the studies on MINT countries are few and have not been thoroughly researched. Our study is significant in three ways: (1) it focuses specifically on the newly coined emerging economic block (MINT); (2) it contributes to the literature on the positive and negative shock of the influences of remittance and financial development on the economic growth; and (3) the study employed nonlinear panel ARDL estimation techniques which enhance the robustness of the study in addressing the research objectives. The remainder part of the paper is structured as follows: the next sections present the reviews of previous empirical studies on the relationships among financial development, remittance, and economic growth; section three deals with the research methodology; in section four, we discussed the results from our analysis; and the last section consists of the discussion and the conclusion of the study.

Several studies have been carried out on financial development and economic growth. A reference could be made to the work of Beck et al. [10], and the study found a significant relationship between financial development, economic growth, and total factor productivity (TFP) growth. The result of Beck et al. [10] was challenged by Christopoulous and Tsionas [19] based on the methodology. However, the findings of Beck et al. [10] were supported by [2, 15, 27, 38], Uddin et al. [53], Smargandi et al. [50], who did similar studies and found a positive influence of financial development 
on economic growth. Though, Nyamango et al. [38] suggested in their study that the influence of financial development in boosting economic growth appears to be weak. More recently, in spite of the arguments, Zhang et al. [59] conducted a study on the "financegrowth relationship" and found a positive relationship between financial development and economic growth. Meanwhile, Herwartz and Walle [24] in their study find the influence of financial development on economic growth to be stronger in developed countries than in developing countries. This finding was corroborated with the studies of Pradhan et al. [47], Peprah et al. [45]. Peprah et al. [45] argued that though a positive relationship between financial developments and economic was found, and a certain financial development level can bring down economic growth in the long-run.

The investigations on the relationship between financial development and remittance abound in the literature. However, the results have been mixed, while some found a positive relationship [12, 21, 29, 49, 54], and some authors could not establish a significant relationship in their studies [5, 18]. Aggarwal et al. [49] in their study investigated the relationship between remittance and financial development using 109 developing countries' data between 1975 and 2007, employed GMM estimation techniques. The study shows a positive, significant, and robust link between remittance and financial development. A similar result was achieved by Williams [54] though employed the same method but with a data for SSA countries. Meanwhile, in the study of Karikari et al. [29] conducted on 50 developing countries in Africa using data from 1990 to 2011 and employed fixed/random effect model found that certain aspects of financial development is been promoted by remittances, and also that the influence of remittance on financial development is found only in the short term and not at the long-run. Moreover, Fromentin [21] investigated the remittances-financial development relationship in the emerging and developing countries, using a data from 1974 to 2014, and Fromentin's PMG. Fromentin study found that a positive long-run relationship exists between remittance and financial development, and concluded that in the long-run, remittance promotes financial development in the developing countries. Recent study by Battacharya et al. [12] was conducted on 57 highest remittance recipients' countries using data from 1992 to 2012 and employed system GMM. The study found a significant long-run relationship between remittances and three alternative indicators of financial development. In contrast, Akkoyunlu [5] and Coulibaly [18] could not establish a significant relationship between remittances and financial development. Coulibaly [18] argued that a piece of strong evidence to support the remittance influence on economic growth could not be established and also find that financial development is not a determinant of remittance.

As for the influence of remittances on economic growth, several authors have investigated the relationship. In the literature, there are three strands, those that found no significant influence of remittance on economic growth $[1,33,34]$, to those that found a positive influence of remittance on economic growth $[3,7$, $9,22,23,26,35-40]$, and those that found the influence of remittance to be negative on economic growth [4, $16,28,39,46,47]$. Though Nyamongo et al. [38], Jawaid and Raza [26] found the influence of remittance on economic growth to be positive, but they argued that the workers' remittance volatility has a significant impact on economic growth. While the study of Meyer and Shera [37] that focus on the six high remittance countries found a positive influence of remittance on economic growth, Odugbesan and Rjoub [39] study was on MINT countries and found that remittance only has a positive significant influence on economic growth in Indonesia and Mexico, while the impact was found to be negative on Nigeria economic growth.

Lastly, the studies on the interactions between remittances, financial development and economic growth in the literature were reviewed. An empirical finding from the work of Betti and Zazzaro [11] shows the existence of complementarity between remittances and bank efficiency in economic growth, and argued that remittances promote growth only in countries whose banks function well. A similar study by Kratou and Gazdar [31] focuses on MENA countries, the results show that the short-run effect of remittances on economic growth that was found is conditional. In other words, it depends on the levels of financial development and institutional quality, respectively. Moreover, Chowdury [17] shows that financial development neither works as a substitute nor a complement for the remittance-growth nexus. It shows further that remittances are effective in promoting economic growth, and also that the influence of financial variables is found to be insignificant. The study concludes that the interaction effect of financial development and remittances is not growth enhancing. More recently, study by Peprah et al. [45], which utilized Ghana data from 1984 to 2015 and employed ARDL, found in the study that the combined effect of financial development and remittances on economic growth was positive and significant. Meanwhile, Sobiech [52] argued that the more financially developed a country is, the smaller the impact of remittances on the economic growth, and suggests that remittances 
can foster growth, but the effect is significant only at low levels of financial development.

\section{Methods}

Our study is to investigate the positive and negative shocks of financial development and remittances on economic growth with special focus on the new emerging economies block (MINT). An annual data spanning from 1980 to 2019 was utilized. Personal remittances received (current US\$) were the proxy for remittances, GDP per capital (current US\$) for the economic growth, while the newly computed financial development index by the International Monetary Fund (IMF) was used as a proxy for financial development. The newly computed financial development index by the IMF combined the depth, access, and efficiency of both the financial institutions and financial markets. Remittances and GDP data were sourced from World Bank Development Indicator [58], while the financial development data were collected from IMF [25].

The study utilizes robust heterogeneous panel methods known as the Pooled Mean Group (PMG) and the Mean Group (MG) estimator for dynamic panels that are non-stationary. The parameters are heterogeneous across groups. In this scenario, such methods are suitable due to the large $\mathrm{T}$ dimensions. Asymptotic large dynamic panels are distinct from the asymptotic of conventional small dynamic panels [14]. For instance, estimators for small panel estimates, like fixed and random effect estimators and generalized method of moments estimators, generally involve the pooling of individual groups and enabling only intercepts to vary through groups. In contrast, slope coefficients are presumed to be homogeneous.

Pesaran et al. [43, 44] state that the assumption of homogeneity of slope parameters is always unacceptable while working with large $T$ panels. Disregarding the heterogeneity of the slope parameter as it occurs can yield contradictory and probably ambiguous outcomes. The MG estimator by Pesaran and Smith [42] and the PMG estimator by Pesaran et al. [43, 44] have been established to catch any possible heterogeneity of slope in the data panel model and any possible distortion that could arise from the usage of conventional approaches like fixed effects and random effects estimators. The MG entails calculating $\mathrm{N}$ time-series regressions and averaging coefficients, while the PMG estimator needs a mixture of pooling and averaging coefficients. In either case, the two estimators use the autoregressive distributive lag (ARDL) framework, which makes the combining of the series $\mathrm{I}(0)$ and I(1). The ARDL panel for the symmetric version is illustrated as:

$$
\begin{aligned}
\Delta \mathrm{GDP}_{i t} & =\vartheta_{0}+\vartheta_{1 i} \mathrm{GDP}_{i, t-1} \\
& +\vartheta_{2 i} \operatorname{REM}_{i, t-1}+\vartheta_{3 i} \mathrm{FD}_{i, t-1} \\
& +\sum_{j-1}^{N 1} \lambda_{i j} \Delta \mathrm{GDP}_{i, t-1} \\
& +\sum_{j-1}^{N 2} \alpha_{i j} \Delta \mathrm{REM}_{i, t-1} \\
& +\sum_{j-1}^{N 3} \delta_{i j} \Delta \mathrm{FD}_{i, t-1} \\
& +\varepsilon_{i}+\mu_{i t}^{i}=1,2, \ldots \ldots N ; \\
& t=1,2, \ldots T
\end{aligned}
$$

where the group-specific effect is denoted by $\varepsilon_{i}$, the groups number is represented by $i$; the group period is depicted by $t, \mathrm{GDP}_{t}$ portrays the logarithm of GDP growth and $\mathrm{FD}_{t}$ mirrors the financial development index. Furthermore, for each cross section, the long-run slope coefficients are estimated as $\frac{\rho_{2}}{\rho_{1}}$ and $\frac{\rho_{3}}{\rho_{1}}$ correspondingly, since in the long-run, it is presumed that $\Delta \mathrm{GDP}_{i, t-j}=0$; $\Delta \mathrm{REM}_{i, t-j}=0$ and $\Delta \mathrm{FD}_{i, t-j}=0$. However, for each cross section, the short-run estimates are gathered as $\alpha_{j}$ and $\delta_{j}$ for remittance and financial development separately. Equation 3 can be restructured to incorporate an ECT as follows:

$$
\begin{aligned}
\Delta \mathrm{GDP}_{i t}= & \theta_{1} v_{i, t-1}+\sum_{j-1}^{N 1} \lambda_{i j} \alpha_{i j} \operatorname{GDP}_{i, t-1} \\
& +\sum_{j-1}^{N 2} \alpha_{i j} \Delta \mathrm{REM}_{i, t-1}+\sum_{j-1}^{N 3} \delta_{i j} \Delta \mathrm{FD}_{i, t-1}+\varepsilon_{i}+\mu_{i t}
\end{aligned}
$$

where $v_{i, t-1}=\mathrm{GDP}_{i, t-1}-\psi_{0}-\psi_{1 i} \mathrm{REM}_{i, t-1}-\psi_{2 i} \mathrm{FD}_{i, t-1}$ is the linear ECT; $\theta 1$ depicts the error-correcting speed of adjustment term, whereas the long-run fundamental parameters have been formerly stated as $\psi_{1 i}=\frac{\rho_{2 i}}{\rho_{1 i}}$ and $\psi_{2 i}=\frac{\rho_{3 i}}{\rho_{1 i}}$. In Eqs. 1 and 2, there are no decompositions of remittance and financial development into negative and positive changes; therefore, symmetric assumption behavior of remittance and financial development on GDP growth under this situation. The asymmetric form of Eq. (1) is indicated beneath and the decomposition of remittances and financial development into positive and negative shocks follows Shin et al. [51]: 


$$
\begin{aligned}
\Delta \mathrm{GDP}_{i t}= & \vartheta_{0}+\vartheta_{1 i} \mathrm{GDP}_{i, t-1} \\
& +\vartheta_{2 i} \mathrm{REM}_{i, t-1}^{+}+\vartheta_{3 i} \mathrm{REM}_{i, t-1}^{-}+\vartheta_{4 i} \mathrm{FD}_{i, t-1}^{+} \\
& +\vartheta_{5 i} \mathrm{FD}_{i, t-1}^{-}+\sum_{j-1}^{N 1} \lambda_{i j} \Delta \mathrm{GDP}_{i, t-1} \\
& +\sum_{j-1}^{N 2}\left(\alpha_{i j}^{+} \Delta \mathrm{REM}_{i, t-j}^{+}+\alpha_{i j}^{-} \Delta \mathrm{REM}_{i, t-j}^{-}\right) \\
& +\sum_{j-1}^{N 3}\left(\alpha_{i j}^{+} \Delta \mathrm{FD}_{i, t-j}^{+}+\alpha_{i j}^{-} \Delta \mathrm{FD}_{i, t-j}^{-}\right) \\
& +\varepsilon_{i}+\mu_{i t}
\end{aligned}
$$

In Eq. 3, the remittance and financial development variables $\mathrm{REM}_{i, t}$ and $\mathrm{FD}_{i t}$ have now been decomposed into $\left(\mathrm{REM}_{i, t}^{+}\right.$and $\left.\mathrm{REM}_{i, t}^{-}\right) \quad$ and $\quad\left(\left(\alpha_{i j}^{+} \Delta \mathrm{FD}_{i, t}^{+}+\alpha_{i j}^{-} \Delta \mathrm{FD}_{i, t}^{-}\right)\right.$, respectively, signifying positive and negative changes of remittance and financial development correspondingly. These decomposed remittance and financial development are explained as follows:

$$
\begin{aligned}
& \mathrm{REM}_{t}^{+}=\sum_{j=1}^{s} \Delta \mathrm{REM}_{i j}^{+}=\sum_{k=1}^{s} \max \left(\Delta \mathrm{REM}_{i j}, 0\right) \\
& \mathrm{REM}_{t}^{-}=\sum_{j=1}^{s} \Delta \mathrm{REM}_{i j}^{-}=\sum_{k=1}^{s} \min \left(\Delta \mathrm{REM}_{i j}, 0\right) \\
& \mathrm{FD}_{t}^{+}=\sum_{j=1}^{s} \Delta \mathrm{FD}_{i j}^{+}=\sum_{k=1}^{s} \max \left(\Delta \mathrm{FD}_{i j}, 0\right) \\
& \mathrm{FD}_{t}^{-}=\sum_{j=1}^{s} \Delta \mathrm{REM}_{i j}^{-}=\sum_{k=1}^{s} \min \left(\Delta \mathrm{FD}_{i j}, 0\right)
\end{aligned}
$$

We can re-specify Eq. 3 to include an error correction. It is depicted as follows: group averages, (2) cross-section regressions of the averages over-time; (3) pooled regressions enabling for fixed or random intercepts; or (4) individual regressions for each group in which the values of the coefficients are averaged through these groups. Accordingly, after these steps, the MG estimator guarantees that intercepts, slope coefficients and error variances will all vary across groups.

Nonetheless, the discrepancy between the MG estimator and the PMG estimator resides in the way the longterm coefficients are viewed. Unlike the MG estimator, the PMG estimator constrains the long-run coefficients to be equal across groups (as in the case of FE estimator). However, the intermediate estimator still allows the intercept, short-run coefficients, and error variances to differ across the groups (as in the case of MG estimator). Owing to the nonlinearity of the variables, Pesaran et al. (1993) establish a high likelihood approach for estimating the parameters. Maximum likelihood is accomplished by applying the product log of the chance of each cross section as described as follows:

$$
\begin{aligned}
\left.I_{T}\left(\gamma^{\iota}, \eta^{\iota},\right\rangle^{2 \iota}\right)= & \left.-\frac{T}{2} \sum_{i=1}^{N} \operatorname{In}(2 \xi\rangle_{i}^{2}\right)-\frac{1}{2} \sum_{i=1}^{N} \frac{1}{\gamma_{i}^{2}} \\
& \left(\Delta y_{i}-\theta_{i} \partial_{i}(\beta)\right\}^{\iota} H_{i}\left\{\Delta y_{i}-\theta_{i} \partial_{i}(\beta)\right\}
\end{aligned}
$$

where $\partial_{i}(\beta)=y_{i, t-1}-X_{i, t-1} \beta_{i} ; H_{i}=I_{T}$ $-W_{i}^{\iota}\left(W_{i}^{\iota} W_{i}\right) W_{i}^{\iota} ; I_{T}$ is an identity matrix of dimension $\mathrm{T}$ and $W_{i}=\left(\Delta y_{i, t-1, \ldots,} \Delta y_{i, t-1, \ldots,} \Delta_{y i, t-p+1}, \Delta X_{i t}, \Delta X_{i, t-1, \ldots,} \Delta X_{i, t-q+1}\right)$.

The estimation procedure of the PMG estimator follows maximum likelihood involving the steps below: (a) Begin with an initial estimate of the long-run coefficient vector, $\widehat{\beta}$; (b) regress $\Delta y_{i}$ on $\widehat{\omega}_{i}$ and $W_{i}$ in order to acquire the coefficients in the short-run and the basic group speed of the adjustment terms; (c) Utilize conditional estimation in (ii) to correct the value of $\beta$; (d) Iterate

$$
\begin{aligned}
\Delta \mathrm{GDP}_{i t}= & \omega_{i} \pi_{i, t-1}+\sum_{j-1}^{N 1} \lambda_{i j} \Delta \mathrm{GDP}_{i, t-1}+\sum_{j-1}^{N 2}\left(\alpha_{i j}^{+} \Delta \mathrm{REM}_{i, t-j}^{+}+\alpha_{i j}^{-} \Delta \mathrm{REM}_{i, t-j}^{-}\right) \\
& +\sum_{j-1}^{N 3}\left(\alpha_{i j}^{+} \Delta \mathrm{FD}_{i, t-j}^{+}+\alpha_{i j}^{-} \Delta \mathrm{FD}_{i, t-j}^{-}\right)+\varepsilon_{i}+\mu_{i t}
\end{aligned}
$$

In Eq. $8, \pi_{i, t-1}$ denote the ECT that addressed the longrun equilibrium in the asymmetric Panel ARDL whereas its linked parameter $\omega_{i}$ is the speed of adjustment term that Checks how long the system would take to return to its long-run whenever there is a shock. In order to produce accurate results, Pesaran and Smith [42] provide four distinct calculation methods by utilizing the MG estimator: (1) generalized time-series regressions of the measures I to (iii) before reaching convergence. In line with the selection process of the fixed effects and random effects, the Hausman test is utilized to select between the estimator of PMG and MG estimators, respectively. As mentioned above, the PMG estimator restricts estimation of the long-run to be the same across all panels. According to Blackburn and Frank [14], when the restrictions are true, the pooling across nations yields efficient 
and reliable estimates. Though, the PMG estimates will generate estimates that are not consistent if the true model is heterogeneous. Thus, the difference in the coefficients estimators is estimated by utilizing the Hausman test. When the null hypothesis is rejected, the PMG estimated will be used. However, if the null hypothesis is not rejected, the MG will be used.

\section{Results and discussion}

It is essential to examine the integration order of variables to ascertain the integration order of variables. The study employs the Im-Pesaran-Shin (IPS) and Levin-LinChu (LLC) unit root tests to verify this integration order. Table 1 illustrates the integration order of the variables used. We first determine the efficient estimator for each of the models specified using the familiar Hausman test. The result of the test is presented in Table 2. Note that only the results obtained from the preferred estimator are reported and interpreted in this paper. As depicted in Table 2, the PMG estimator, the efficient estimator under the null hypothesis, is primarily preferred. The empirical estimates are discussed under two main headings. First, we evaluate the role without asymmetry and with asymmetry for the impact of remittance and financial development on GDP growth in MINT economies utilizing a complete dataset spanning between 1980 and 2018.

Table 1 Unit root section

\begin{tabular}{lcclll}
\hline Variable & \multicolumn{2}{l}{$\begin{array}{l}\text { Im-Pesaran-Shin unit root } \\
\text { test }\end{array}$} & & \multicolumn{2}{l}{$\begin{array}{l}\text { Levin-Lin-Chu unit root } \\
\text { test }\end{array}$} \\
\cline { 2 - 3 } \cline { 5 - 6 } & Level & 1st difference & & Level & 1st difference \\
\hline InGDP & 1.853 & $-6.782^{* *}$ & & 0.169 & $-4.931^{* *}$ \\
InREM & 0.866 & $-7.130^{* *}$ & & -0.935 & $-5.448^{* *}$ \\
FDI & -1.201 & $-8.668^{* *}$ & & $-2.120^{*}$ & \\
\hline
\end{tabular}

**, ${ }^{*}$ denotes $1 \%$ and $5 \%$ significant level, respectively

\section{Hausman test}

The Hausman test statistics is depicted in Table 2 for all the regressors without asymmetry and with asymmetry in this study. The hypothesis for the Hausman test indicates that MG and PMG estimates are not statistically different. The null hypothesis depicts the PMG is more effective, whereas the alternative hypothesis illustrates that the MG is more effective. The study employs the null hypothesis since the $P$ value $>0.05$ in the case of without asymmetry and with asymmetry. Thus, the study fails to reject the null hypothesis of homogeneity. Therefore, the PMG estimator is braced by the two models. The next stage is to conduct the PMG technique without asymmetry and with asymmetry, respectively.

\section{Panel regression outcomes}

Having determined the integration characteristics of the variables under scrutiny, we then continue to evaluate the long-term and short-term dynamics of the GDP growth-remittance and GDP growth-financial development linkages. The findings of the estimation utilizing the complete sample are described in Table 3. The first four columns of the table show long- and short-run regression outcomes without asymmetry. In the long-run, findings revealed as follows: (i) positive and significant link between remittance and GDP growth. It implies that a $0.263 \%$ increase in GDP growth is due to $1 \%$ increase in remittance. These findings support the conclusions reached by previous studies $[1,60]$, which implies that remittances influx into the MINT countries were channeled toward investment and production that support economic growth, (ii) Financial development has a positive impact on GDP growth. It illustrates that $1 \%$ increase in financial development will increase growth by $2.406 \%$. These findings align with those of Zhang et al. [59] and Bist [13] which supports a "finance-growth" relationship indicating an improved and deepened financial system is bedrock for economic growth in the MINT countries. Also, in the short-run, findings revealed that all the

Table 2 Hausman MG PMG, Sigmamore

\begin{tabular}{|c|c|c|c|c|c|c|c|c|}
\hline \multirow[t]{2}{*}{ Variable } & \multicolumn{4}{|c|}{ Without asymmetry } & \multicolumn{4}{|c|}{ With asymmetry } \\
\hline & MG & PMG & Difference & S.E & MG & PMG & Difference & S.E \\
\hline REM & -0.169 & 0.2693 & -0.438 & 0.414 & & & & \\
\hline FD & 10.27 & 2.400 & 7.872 & 6.095 & & & & \\
\hline $\operatorname{REM}_{t-1}^{+}$ & & & & & -0.077 & 0.312 & -0.389 & 0.415 \\
\hline $\mathrm{REM}_{t-1}^{-}$ & & & & & -0.111 & 0.230 & -0.3418 & 0.347 \\
\hline $\mathrm{FD}_{t-1}^{+}$ & & & & & 9.456 & 1.838 & 7.617 & 6.291 \\
\hline $\mathrm{FD}_{t-1}^{-}$ & & & & & 11.53 & 3.956 & 7.575 & 6.808 \\
\hline Hausman Test & 0.36 & 0.82 & & & & & & \\
\hline
\end{tabular}


Table 3 Panel regression outcomes. Source: Authors Collation with Stata 15

\begin{tabular}{|c|c|c|c|c|c|c|c|c|}
\hline \multirow[t]{2}{*}{ Regressors } & \multicolumn{4}{|c|}{ Without asymmetry } & \multicolumn{4}{|c|}{ With asymmetry } \\
\hline & Coefficient & SE & T-Statistic & Prob & Coefficient & SE & T-Statistic & Prob \\
\hline \multicolumn{9}{|c|}{ Long-run estimation } \\
\hline REM & 0.263 & 0.083 & 3.220 & 0.001 & & & & \\
\hline $\operatorname{REM}_{t-1}^{+}$ & & & & & 0.312 & 0.102 & 3.060 & 0.002 \\
\hline $\mathrm{REM}_{t-1}^{-}$ & & & & & 0.230 & 0.102 & 2.240 & 0.025 \\
\hline FD & 2.406 & 0.499 & 4.810 & 0.000 & & & & \\
\hline $\mathrm{FD}_{t-1}^{+}$ & & & & & 3.956 & 0.803 & 2.290 & 0.022 \\
\hline $\mathrm{FD}_{t-1}^{-}$ & & & & & 1.8393 & 1.267 & 3.120 & 0.002 \\
\hline \multicolumn{9}{|c|}{ Short-run estimation } \\
\hline $\mathrm{ECM}(-1)$ & -0.92 & 0.059 & -3.735 & 0.000 & -0.857 & 0.047 & -2.101 & 0.035 \\
\hline REM & 0.102 & 0.067 & 1.520 & 0.129 & & & & \\
\hline $\mathrm{REM}_{t-1}^{+}$ & & & & & 0.384 & 0.094 & 0.410 & 0.683 \\
\hline $\operatorname{REM}_{t-1}^{-}$ & & & & & 0.045 & 0.085 & 0.530 & 0.595 \\
\hline FD & 0.260 & 0.264 & 0.990 & 0.324 & & & & \\
\hline $\mathrm{FD}_{t-1}^{+}$ & & & & & 0.312 & 0.431 & 0.720 & 0.469 \\
\hline $\mathrm{FD}_{t-1}^{-}$ & & & & & -0.022 & 0.708 & -0.035 & 0.974 \\
\hline
\end{tabular}

regressors have insignificant interconnection on GDP growth. As projected, the ECM $(-0.92)$ is negative and statistically significant, which illustrates a faster return to equilibrium when there is an imbalance.

When asymmetry is included in the interaction, the calculated coefficients indicate an astonishing outcome. The long-run outcomes of the NARDL disclosed; (i) a positive shock in remittances has a positive and significant effect on GDP growth (0.312), signifying that any positive shock in remittance triggers real growth in the MINT economies. This implies that remittances have a significant effect on the economic growth of the MINT nations. On the flip-side, a negative shock in remittance has a positive and significant effect on GDP growth (0.230), signifying that a negative remittance shock triggers real growth in the MINT economies which implies that the general public is able to react to reduced remittances inflow and mitigate on its effects on economic growth in the long-run. Therefore, both negative and positive shock in remittances triggers economic expansion in the MINT economies. Thus, policymakers in the MINT economies should formulate policies that will encourage the flow of money to the home country since it stimulates growth in the economy; though most remittances are channeled to consumption. (ii) A positive shock in financial development impacts economic growth positively (0.956), demonstrating that a positive shock in financial development increases economic growth in the MINT economies. On the other hand, a negative shock in financial development impacts growth positively (1.8393). This infers that a negative shock in financial development triggers growth positively in the MINT nations. Furthermore, we observed that the coefficient of positive shock in financial development is greater than the coefficient of negative shock in financial development. The main reason behind the positive impact of financial development on economic growth is that by raising the savings rate, mobilizing and pooling funds, creating investment information, enabling and promoting foreign capital inflows, and optimizing capital allocation, financial development supports economic growth through capital accumulation and technological advancement. In the short-run, no significant interrelationship exists between real growth and regressors. As anticipated, the ECM $(-0.85)$ is negative and statistically significant, which illustrates a return to equilibrium when there is an imbalance.

\section{Conclusions}

This research offers a perspective on the nonlinear finance-growth and remittance-growth relationship in MINT nations utilizing both linear and nonlinear ARDL approaches between 1980 and 2019. The contributions of this research to the existing literature on the association between financial development, remittances, and economic growth are detailed below. First, most past researches have measured financial development with variables such as banking sector domestic credit, domestic credit to private sector, money and quasi money as a percentage of GDP, private domestic credit to private sector or financial sector domestic credit, but all these are only indicators of the measure of financial depth and financial markets most often are been left out in 
the discussion or sometimes not well represented. The financial sector and its development have evolved over the years to a bigger more encompassing measure of efficiency, depth, and accessibility. The contribution of the financial sector would be irrelevant if its lacks efficiency and accessibility. We made use of a newly computed financial development index by the IMF that combined the depth, access, and efficiency of both the financial institutions and financial markets.

Second, in this research, we employed a nonlinear panel ARDL estimation technique which enhances the robustness in the study of the relationship between financial development, remittances and economic growth, and we found that the negative and positive shock of financial development and remittance drives MINT countries economic growth. This is an indication that financial development and remittances are of great relevance in the MINT countries. Policymakers and government institutions are to ensure that the remittances coming into the MINT countries contribute to economic growth by fostering growth in the financial development and take appropriate measures to engender efficient financial development policies and institutional framework to robust technological changes that can drive the effective and desired economic growth which will greatly be of help to MINT economies. When establishing growth strategies in MINT countries, policymakers should consider financial development. To maximize the advantages of industrialization, it is necessary to encourage financial sector development, since the findings revealed that financial development impacts growth positively. The research also indicated that financial structure is important; as a result, measures to improve both financial institutions and financial markets are required in the MINT economies. Although the present research utilized a novel technique to assess the linkage between financial development, remittance, and economic growth, there are few limitations. First, the study only used both financial development and remittance as determinants of economic growth. Future studies should incorporate other determinants of economic growth such as inflation, gross capital formation and trade openness into the model. Secondly, asymmetric causality was not explored in this study. Thus, future research should look into this.

\footnotetext{
Abbreviations

ARDL: Autoregressive distributed lag; BRICS: Brazil, Russia, India, China, South Africa; GMM: Generalized method of moments; MG: Mean group; MINT: Mexico, Indonesia, Nigeria, Turkey; PMG: Pooled mean group.
}

Authors' contributions

JAO conceptualized the research idea and performed the introduction and literature review writing. The methodology and formal analysis was performed by TSA, while GO drafted the discussion and conclusion. JAO, TSA, and GO performed the review and editing, and they all have read and agreed to the publishing of the revised version. All authors read and approved the final manuscript.

\section{Funding}

This study received no specific financial support.

Availability of data and materials

Data used in this study can be found in the cited link.

\section{Declarations}

\section{Competing Interests}

The authors declare that there are no conflicts of interests regarding the publication of this paper.

Received: 31 March 2021 Accepted: 25 July 2021

Published: 26 November 2021

\section{References}

1. Adams S, Klobodu EKM (2016) Remittances, regime durability and economic growth in Sub-Saharan Africa (SSA). Econ Anal Policy 50:1-8

2. Adamu AM, Kabuga NA, Suleiman HH (2015) Remittance, aid, foreign direct investment, financial development and economic growth in Nigeria: a time series analysis. In: Proceedings of 1st international conference and doctoral colloquium on the theme: "development in africa: perspectives, issues and trends", faculty of social and management sciences, Bayero University Kano, Nigeria held between 17th-18th November, pp 720-733

3. Adarkwa MA (2015) Impact of remittances on economic growth: evidence from selected West African countries (Cameroon, Cape Verde, Nigeria and Senegal). Afr Hum Mob Rev 1(2):178-202

4. Ahmed MS (2010) Migrant workers remittance and economic growth: evidence from Bangladesh. ASA Univ Rev 4(1):1-13

5. Akkoyunlu S (2013) Remittances and financial development: Is there a direct link. In: Evidence from Turkey data, presented by mrs. suleakkoyunlu at the conference on" migration: global development, new frontiers, pp 10-13

6. Asongu S, Akpan US, Isihak SR (2018) Determinants of foreign direct investment in fast-growing economies: evidence from the BRICS and MINT countries. Financ Innov 4(1):26

7. Azam M (2015) The role of migrant workers remittances in fostering economic growth: the four Asian developing countries' experiences. Int J Soc Econ 42(8):690-705

8. Bang JT, Mitra A, Wunnava PV (2016) Do remittances improve income inequality? An instrumental variable quantile analysis of the Kenyan case. Econ Model 58:394-402. https://doi.org/10.1016/j.econmod.2016.04.004

9. Bayar $Y$ (2015) Impact of remittances on the economic growth in the transitional economies of the European Union. Pet-Gas Univ Ploiesti Bull Techn Ser 67(3)

10. Beck T, Levine R, Loayza N (2000) Finance and the sources of growth. J Financ Econ 58(1-2):261-300. https://doi.org/10.1016/S0304-405X(00) 00072-6

11. Bettin G, Zazzaro A (2012) Remittances and financial development: Substitutes or complements in economic growth? Bull Econ Res 64(4):509-536

12. Bhattacharya M, Inekwe J, Paramati SR (2018) Remittances and financial development: empirical evidence from heterogeneous panel of countries. Appl Econ 50(38):4099-4112

13. Bist JP (2018) Financial development and economic growth: evidence from a panel of 16 African and non-African low-income countries. Cogent Econ Finance 6(1):1449780 
14. Blackburne EF III, Frank MW (2007) Estimation of nonstationary heterogeneous panels. Stand Genomic Sci 7(2):197-208

15. Bojanic AN (2012) The impact of financial development and trade on the economic growth of Bolivia. J Appl Econ 15(1):51-70. https://doi.org/10. 1016/S1514-0326(12)60003-8

16. Chami R, Fullenkamp C, Jahjah S (2005) Are immigrant remittance flows a source of capital for development? IMF Staff Pap 52(1):55-81

17. Chowdhury M (2016) Financial development, remittances and economic growth: evidence using a dynamic panel estimation. Margin J Appl Econ Res 10(1):35-54

18. Coulibaly D (2015) Remittances and financial development in Sub-Saharan African countries: a system approach. Econ Model 45:249-258

19. Christopoulos DK, Tsionas EG (2004) Financial development and economic growth: evidence from panel unit root and cointegration tests. J Dev Econ 73(1):55-74. https://doi.org/10.1016/j.jdeveco.2003.03.002

20. Durotoye A (2014) The MINT countries as emerging economic power bloc: Prospects and challenges. Dev Country Stud 4(15):99-107

21. Fromentin $V$ (2017) The long-run and short-run impacts of remittances on financial development in developing countries. Q Rev Econ Finance 66:192-201

22. Giuliano P, Ruiz-Arranz M (2009) Remittances, financial development, and growth. J Dev Econ 90(1):144-152

23. Goschin Z (2014) Remittances as an economic development factor. Empirical evidence from the CEE countries. Procedia Econ Finance 10:54-60

24. Herwartz H, Walle YM (2014) Determinants of the link between financial and economic development: evidence from a functional coefficient model. Econ Model 37:417-427. https://doi.org/10.1016/j.econmod.2013. 11.029

25. International Monetary Fund (2019) Financial Development Index Database. http://data.imf.org

26. Jawaid ST, Raza SA (2016) Effects of workers' remittances and its volatility on economic growth in South Asia. Int Migr 54(2):50-68

27. Jedidia KB, Boujelbène T, Helali K (2014) Financial development and economic growth: new evidence from Tunisia. J Policy Model 36(5):883-898. https://doi.org/10.1016/j.jpolmod.2014.08.002

28. Karagoz K (2009) Workers'remittances and economic growth: Evidence from Turkey. J Yasar Univ 4(13):1891-1908

29. Karikari NK, Mensah S, Harvey SK (2016) Do remittances promote financial development in Africa? Springerplus 5(1):1011

30. Kokotović F, Kurečić $P$ (2016) The MINT countries: a regression analysis of the selected economic features. Int J Manag Sci Bus Administ 2(5):21-31

31. Kratou H, Gazdar K (2015) Addressing the effect of workers' remittance on economic growth: evidence from MENA countries. Int J Soc Econ

32. Kuckulenz A, Buch CM (2004) Worker Remittances and Capital Flows to Developing Countries.(ZEW Discussion Papers No. 04-31)

33. López MV, Ascencio FL (2017) A spatial approach to the link between remittances and regional growth in Mexico. MigracionesInternacionales 5(18):7-41

34. Lim S, Simmons WO (2015) Do remittances promote economic growth in the Caribbean Community and Common Market? J Econ Bus 77:42-59

35. Marwan NF, Kadir NAA, Hussin A, Zaini AA, Rashid MEA, Helmi ZAG (2013) Export, aid, remittance and growth: evidence from Sudan. Procedia Econ Finance 7:3-10

36. Matuzeviciute K, Butkus M (2016) Remittances, development level, and long-run economic growth. Economies 4(4):28

37. Meyer D, Shera A (2017) The impact of remittances on economic growth: an econometric model. Economia 18(2):147-155

38. Nyamongo EM, Misati RN, Kipyegon L, Ndirangu L (2012) Remittances, financial development and economic growth in Africa. J Econ Bus 64(3):240-260

39. Odugbesan JA, Rjoub H (2019) The causal relationship between economic growth and remittance in mint countries: an ARDL bounds testing approach to cointegration. J Acad Res Econ 11(2):310-329
40. Oshota SO, Badejo AA (2015) Impact of remittances on economic growth in Nigeria: further evidence. Econ Bull 35(1):247-258

41. Öztürk Z, Yildirim E (2015) Environmental kuznets curve in the MINT countries: evidence of long-run panel causality test. Int J Econ Soc Res 11(1):175-183

42. Pesaran MH, Smith R (1995) Estimating long-run relationships from dynamic heterogeneous panels. J Econom 68(1):79-113

43. Pesaran MH, Shin Y, Smith RP (1999) Pooled mean group estimation of dynamic heterogeneous panels. J Am Stat Assoc 94(446):621-634

44. Pesaran MH, Shin Y (1995) Long run structural modeling, Cambridge Department of Applied Economics University of Cambridge (No. 9419). DAE Working Paper

45. Peprah JA, KwesiOfori I, Asomani AN (2019) Financial development, remittances and economic growth: a threshold analysis. Cogent Econ Finance $7(1): 1625107$

46. Pradhan KC (2016) Does remittance drive economic growth in emerging economies: evidence from FMOLS and Panel VECM. Theor Appl Econ 23(4)

47. Pradhan RP, Arvin MB, Hall JH, Nair M (2016) Innovation, financial development and economic growth in Eurozone countries. Appl Econ Lett 23(16):1141-1144. https://doi.org/10.1080/13504851.2016.1139668

48. Ratha D (2003) Workers' remittances: an important and stable source of external development finance. Global Development Finance (23 April 2003), World Bank

49. ReenaAggarwal A-K, Pería MSM (2011) Do remittances promote financial development? J Dev Econ 96:255-264

50. Samargandi N, Fidrmuc J, Ghosh S (2015) Is the relationship between financial development and economic growth monotonic? Evidence from a sample of middle-income countries. World Dev 68:66-81. https://doi. org/10.1016/j.worlddev.2014.11.010

51. Shin Y, Yu B, Greenwood-Nimmo M (2014) Modelling asymmetric cointegration and dynamic multipliers in a nonlinear ARDL framework. In: Festschrift in honor of Peter Schmidt. Springer, New York, NY, pp 281-314

52. Sobiech I (2019) Remittances, finance and growth: does financial development foster the impact of remittances on economic growth? World Dev 113:44-59

53. Uddin GS, Sjö B, Shahbaz M (2013) The causal nexus between financial development and economic growth in Kenya. EconomicModelling 35:701-707. https://doi.org/10.1016/j.econmod.2013.08.031

54. Williams K (2016) Remittances and Financial development: evidence from Sub-Saharan Africa. Afr Dev Rev 28(3):357-367

55. World Bank (2017) Migration and development Brief 21. Washington D.C.: Migration and Remittances Team. Development Prospect Group

56. World Bank (2018a) Global Economic Prospect. Online: www.worldbank. org/en/publication/global-economic-prospects

57. World Bank (2018b) Migration and Development Brief 30. Washington D.C.: Migration and Remittances Team. Development Prospect Group

58. World Bank (2019) World Bank development indicators. http://databank. worldbank.org/data/home.aspx

59. Zhang J, Wang L, Wang S (2012) Financial development and economic growth: recent evidence from China. J Comp Econ 40(3):393-412. https:// doi.org/10.1016/j.jce.2012.01.001

60. Zghidi N, Sghaier IM, Abida Z (2018) Remittances, institutions, and economic growth in North African Countries. J Knowl Econ 9(3):804-821

\section{Publisher's Note}

Springer Nature remains neutral with regard to jurisdictional claims in published maps and institutional affiliations. 